\title{
Introducing a Third Disulfide Bond to Ribonuclease T1 and Expression of the Mutant Protein Using the Fusion Protein Method ${ }^{\#}$
}

\author{
Jeanne Adiwinata Pawitan, dr, $\mathrm{PhD}$; Hiroshi Morioka, $\mathrm{PhD} * *$; Satoshi Nishikawa, $\mathrm{PhD}$ ***; \\ Seiichi Uesugi, $\mathrm{PhD} * * * *$
}

\begin{abstract}
Abstrak
Perhitungan dinamika molekular meramalkan bahwa pembentukan ikatan disulfida yang ketiga pada RNase Tl, yaitu antara Tyr 24 dan Asn 84, mungkin terjadi, tanpa menyebabkan perubahan pada catalytic site nya. Gen untuk RNase T1 mutan (Tyr $24 \rightarrow$ Cys 24 , Asn $84 \rightarrow$ Cys 84 ) dibuat dengan cara cassette mutagenesis dengan menggunakan gen yang dibuat secara kimia. Untuk mengurangi aktivitas nukleolitik enzim pada keadaan in vivo, gen dièkspresikan dalam E. coli sebagai protein gabungan yang dihubungkan pada protein lain oleh metionin baik pada ujung - $N$ maupun - C. Sesudah dibebaskan dari protein gabungan karena pemotongan pada batas metionin oleh sianogen bromida, RNase T1 mutan dimurnikan dengan menggunakan kromatografi kolom dan HPLC. Aktivitas nukleolitik terhadap pGpC kurang lebih sama dengan RNase T1, tetapi ketahanan RNase T1 mutan terhadap panas kurang lebih $10^{\circ} \mathrm{C}$ lebih tinggi.
\end{abstract}

\begin{abstract}
Molecular dynamic calculation has predicted that it is possible to form a third disulfide bond in RNase TI, between Tyr 24 and Asn 84, without major changes at the catalytic site. The gene for the mutant RNase T1 (Tyr24 -..> Cys 24, Asn84 ...> Cys84), was constructed by the cassette mutagenesis method using a chemically synthesized gene. In order to reduce the nucleolytic activity of the enzyme in vivo, this gene was expressed in $E$. coli as a fused protein connected through methionin residues to an other protein at both the $\mathrm{N}$ - and $\mathrm{C}$-termini. After liberation from the fused protein by cleavage with cyanogen bromide at the methionin junctions, the mutant $R$ Nase T1 was purified by column chromatography and HPLC. The nucleolytic activity with regard to pGpC was about the same as with RNase $T I$, but the mutant's heat resistance was about $10^{\circ} \mathrm{C}$ higher.
\end{abstract}

Keywords : Protein engineering, Chemically synthesized gene, Phosphotriester method, Mutant enzyme, Heat resistance.

\section{INTRODUCTION}

Ribonuclease T1 (RNase T1) from Aspergillus oryzae is an important enzyme in RNA research because it specifically hydrolyzes the phosphodiester linkages of guanosine $3^{\prime}$-phosphate residues in single stranded RNA.1,2 It is a small (104 a.a.) acidic and globular protein containing two disulfide bonds (between Cys2 and Cys10, Cys6 and Cys103). This enzyme's optimal temperature is $37^{\circ} \mathrm{C}$, and at $50^{\circ} \mathrm{C}$ its activity has dropped considerably, while in RNA research sometimes we have to use higher temperatures to hydrolyze compact structured RNA. Therefore, we aimed to engineer a thermally more stable enzyme.

Among fungal ribonucleases, there are at least two disulfide bonds. In ribonuclease $\mathrm{F} 1$, there is no disulfide bond between Cys2 and Cys10 as in ribonuclease T1, but, instead, it has a disulfide bond between Cys24 and Cys84 (fig.1).

\# This work has been conducted in the Faculty of Pharmaceutical Sciences, Osaka University, Osaka, Japan

* Department of Histology, Faculty of Medicine, University of Indonesia, Jakarta, Indonesia

** Department of Biology, Massachusetts Institute of Technology, Boston, USA

*** Department of Molecular and Cellular Biology, Fermentation Research Institute, Industrial Science and Technology Agency, Ministry of International Trade and Industry, Tokyo, Japan

**** Department of Pharmaceutical Chemistry, Faculty of Pharmaceutical Sciences, Osaka University, Osaka, Japan. 
In RNase $\mathrm{T} 1$, residues number 24 and 84 are far from the catalytic site, and molecular dynamics calculation has hypothesized the possibility of the formation of a disulfide bond between these residues without a reliable change at the catalytic site.

Disulfide bonds have been succesfully introduced into proteins by site directed mutagenesis, ${ }^{3,4,5}$ and some of these mutant proteins are thermally more stable than their respective wild type proteins. ${ }^{3,4}$

Therefore, by protein engineering techniques we have changed Tyr 24 to Cys 24 and Asn 84 to Cys 84 and investigated the activity and structural stability of the mutant enzyme (RNase T1S).

\section{MATERIALS AND METHOD}

\section{Materials}

T4 DNA ligase, polynucleotide kinase and various restriction enzymes were purchased from Takara Shuzo (Kyoto, Japan) or New England Biolabs (Beverly, MA, U.S.A). The RNase T1 was a gift from Sankyo (Tokyo, Japan).

All materials were of reagent grade and were obtained from commercial sources as described previously. ${ }^{1}$ Oligodeoxyribonucleotides were synthesized by the phosphotriester method ${ }^{6}$ in an Apllied Biosystem synthesizer.

Construction of a mutant gene for RNase T1S and its expression plasmid.

The construction of the gene for the RNase T1S was performed in the same way as reported previously by Ikehara et al.' Segments II' and IV ' ${ }^{\prime}$ were used instead of segments II and IV as shown in fig.2. Segment II', encoding Cys 24 instead of Tyr24 was synthesized from oligonucleotide MU5 (24C), d(CAGGCTGCTGGTGT) and oligonucleotide ML6 (24C), d (GCAGCTGACAGCCAG) (italics indicate the changed codons). Segment IV $c^{\prime}$, encoding Cys84 instead of Asn84 and used for the insertion of the mutant gene (Tye24 ---> Cys 24, Asn 84 ---> Cys84) into the BgIII site of pIGF8, was synthesized from oligo-nucleotide MU17 (84C), d (TGTCAGCTCGCTGGC), ML 17 (84C), d (GAAGCTGACAGTTTTCGTTG), U21C, d(ACCATGCA) and L21C, d (GATCTGCATGGTGCATTC) instead of oligonucleotides U17, L17, U21 and L21. Other oligonucleotides and segments used were the same as those synthesized and described by Ikehara et al. ${ }^{6}$ Plasmid pIGF8 $(5 \mu \mathrm{g})$ was digested by $\mathrm{BgIII}$ ( 30 units) at $37^{\circ} \mathrm{C}$ for 24 hours. After ethanol precipitation, linear plasmid DNA were treated with calf intestine alkaline phosphatase $(0.25 \mathrm{U})$ to remove the $5^{\prime}$ - terminal phosphates, phenol extracted, ethanol precipitated and ligated with the synthetic mutant gene. This was designed to be expressed as a fused protein with a portion of hGH and IGF-I at the $\mathrm{N}$ - and C-terminal, under the control of Trp promoter as described by Nishikawa. ${ }^{7}$ Desired plasmid was obtained from transformant of E.coli $\mathrm{Hb} 101$ by standard procedures. The position and the nucleotide sequence of the RNase T1S gene (Tyr 24 ---> Cys24, Asn 84 --.> Cys84) was confirrmed by restriction analysis and the dideoxy method. $^{8}$

\section{Expression of the mutant gene, refolding and purification of RNase T1S.}

The recombinant which harbored the plasmid pT1S was induced by the addition of 3-indoleacrylic acid, and the monitoring of the expression of the mutant gene was performed as described by Ikehara et al. ${ }^{1}$ We started the purification using 51 culture grown to latelog phase. Harvested cells were suspended in $50 \mathrm{mM}$ Tris/HCl (pH 8.0), $30 \mathrm{mM} \mathrm{NaCl} / 1 \mathrm{mM}$ EDTA at a concentration of $0.1 \mathrm{~g} \mathrm{cell} / \mathrm{ml}$. The suspension of cells was treated with lysozyme (final concentration, $1 \mathrm{mg} / \mathrm{ml}$ ) at $0^{\circ} \mathrm{C}$ for $60 \mathrm{~min}$, and then the mixture was treated with DNase (final concentration $1.5 \mu \mathrm{g} / \mu \mathrm{l}$ ) at $0^{\circ} \mathrm{C}$ for $30 \mathrm{~min}$ and centrifuged at $28,000 \mathrm{xg}$ for $40 \mathrm{~min}$. The precipitate was dissolved in the standard buffer ( $20 \mathrm{mM} \mathrm{Tris} / \mathrm{HCl} \mathrm{pH} \mathrm{7.5,10} \mathrm{mM} \mathrm{2-mercapto} \mathrm{ethanol),}$ which contained $7 \mathrm{M}$ urea and was left at $4^{\circ} \mathrm{C}$ overnight until all precipitates had dissolved.

The subsequent procedures : DEAE - cellulose column chromatography (DE 52, $3 \times 6 \mathrm{~cm}$ ) and cyanogen bromide treatment were basically the same as reported previously. ${ }^{9,10}$ Cyanogen bromide treatment was performed without $10 \mathrm{mM} 2$-mercaptoethanol. ${ }^{7}$ After separation from cyanogen bromide, the mixture was subjected to refolding procedure, in $10 \mathrm{mM}$ $(20 \mathrm{mM}-10 \mathrm{mM})$, then in $50 \mathrm{mM}$ Tris $\mathrm{HCl}(\mathrm{pH} 7.5)$ and $100 \mathrm{mM} \mathrm{NaCl}$. The refolded enzymes were purified subsequently by $\mathrm{Q}$ sepharose column chromatography $(2.4 \times 13.5 \mathrm{~cm})$, anion-exchange HPLC (mono Q,FPLC, Pharmacia), with a linear gradient of $\mathrm{NaCl}$ $(0.15-0.45 \mathrm{M})$ in $20 \mathrm{mM}$ Tris/ $\mathrm{HCl}(\mathrm{pH} 7.5)$ and finally subjected to sephadex G25 column chronatography $(0.5 \times 20 \mathrm{~cm})$ to remove salts. The purity of the mutant enzyme was checked by SDS-polyacrylamide gel electrophoresis and the protein concentrations from each step were determined by Lowry's method or, in the case of the purified mutant enzyme, by using a modified molar absorption coefficient $(\Sigma 278=$ $\left.19.830 \mathrm{M}^{-1} \mathrm{~cm}^{-1}\right)$, which was derived from those of 

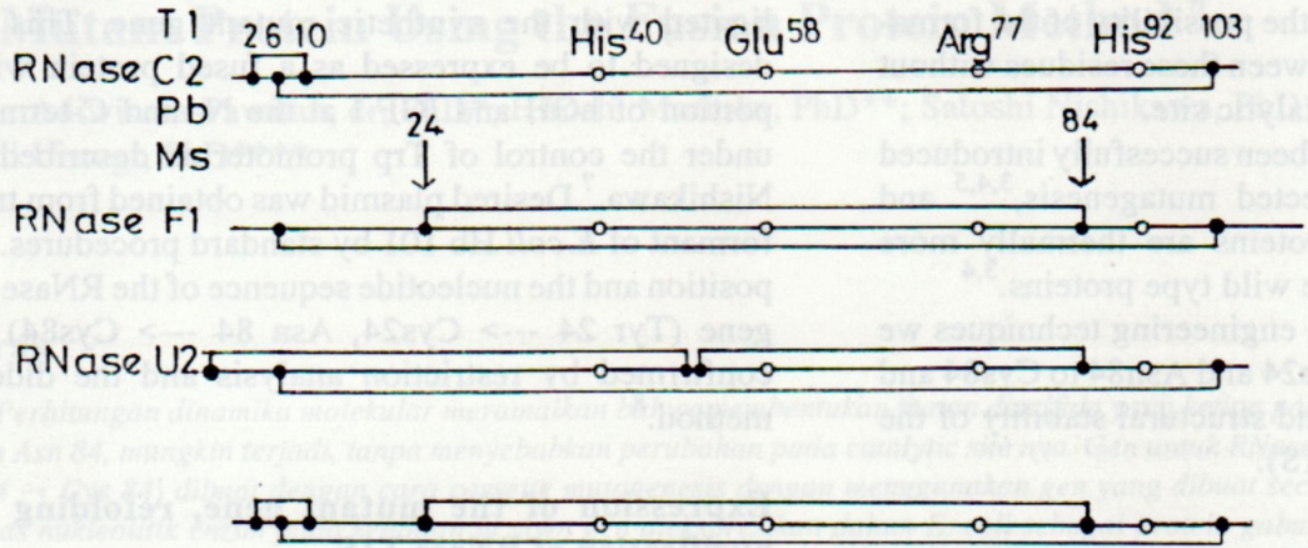

RNase TIS

Figure 1. Schematic alignment of disulfide bonds in fungal ribonucleases. Closed circles indicate cystein, and open circles indicate active site residues: His 40, Glu58, Arg77 and His92.

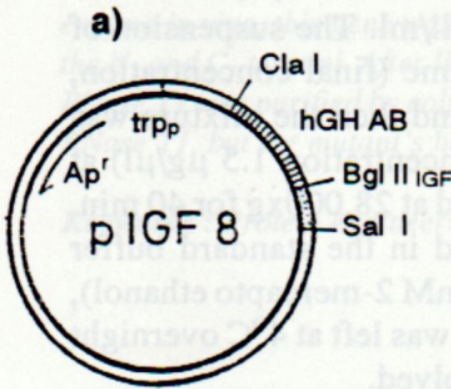

Bgl II<smiles>C[AlH]</smiles>

DNA Ligase

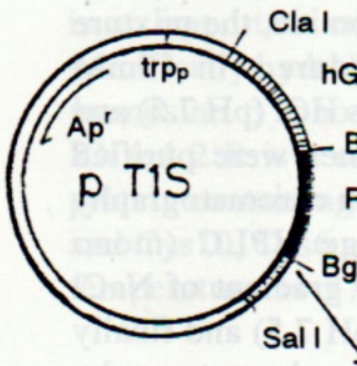

Cla 1
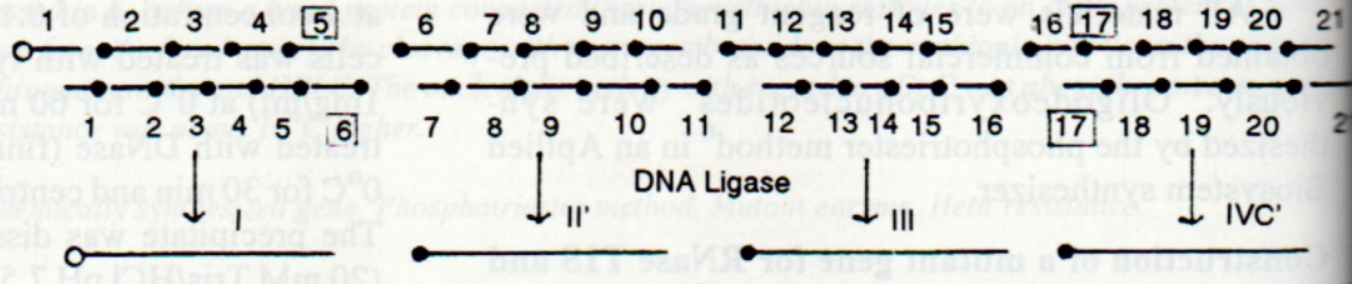

17. $18 \quad 19 \quad 20$
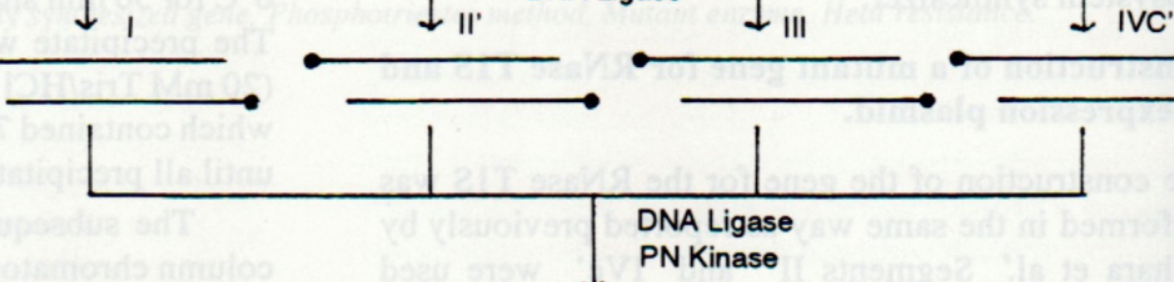

Bgl II

Mutant RNase T1 gene

b)

Figure 2. Synthesis of $\{$ Nase TIS gene and construction of pTIS.

(a). Closed circles indicate 5 '-phosphate, and open circles indicate 5 '-hydroxyl groups. The gene for RNaseTIS was inserted at the BgIII site of plGF8.

(b). Schematic representation of the structure of the fused protein. The sites of cleavage by treatment with cyanogen bromide are marked by arrows. 
RNase T1 $\left(\sum 278=21.170 \mathrm{M}^{-1} \mathrm{~cm}^{-1}\right)$ and tyrosine $\left(\sum\right.$ $\left.278=1.340 \mathrm{M}^{-1} \mathrm{~cm}^{-1}\right)$.

\section{Analyis of the nucleolytic activity}

Nucleolytic activity was measured by analysis of the cleavage of [ $\left.5^{\prime}-32 \mathrm{P}\right] \mathrm{GpC}(200 \mathrm{cpm} / \mathrm{pmol}) .{ }^{1,10}$

The standard reaction mixture contained $150 \mathrm{mM}$ [5'-32P] GpC, $50 \mathrm{mM}$ Tris/HCl (pH 7.5), 1mM EDTA and $5 \mathrm{pg} / \mu \mathrm{l}$ RNase $\mathrm{T} 1$ or the mutant enzyme in a volume of $20 \mu \mathrm{l}$ at $37^{\circ} \mathrm{C}$. The reaction was stopped by $0.2 \mathrm{~N} \mathrm{HCl}$ at $2,5,10$ and $15 \mathrm{~min}$. The product of the reaction, $\left[5^{\circ}-32 \mathrm{P}\right] \mathrm{Gp}$, was separated from $\left[5^{\circ}-\right.$ $32 \mathrm{P}] \mathrm{GpC}$ by DEAE-cellulose thin layer (CEL 300 DEAE/HR-2/15, Macherey-Nagel) chromatography by using a partially hydrolized RNA solution (homomixture VI) as the solvent system and detected by autoradiogram $^{11}$. The radioactivity of each spot was measured in a liquid scintillation counter. To get the activity-temperature profile, the reaction was performed at $37^{\circ} \mathrm{C}, 45^{\circ} \mathrm{C}, 50^{\circ} \mathrm{C}, 55^{\circ} \mathrm{C}, 60^{\circ} \mathrm{C}$ and $70^{\circ} \mathrm{C}$, and repeated 4 times.

\section{Circular dichroism spectroscopy}

CD spectra were recorded on a Jasco J-500 spectropolarimeter. To get the $\mathrm{CD}$-temperature profile, measurements were taken at $5^{\circ} \mathrm{C}, 25^{\circ} \mathrm{C}, 30^{\circ} \mathrm{C}, 35^{\circ} \mathrm{C}, 40^{\circ} \mathrm{C}$, $45^{\circ} \mathrm{C}, 50^{\circ} \mathrm{C}, 55^{\circ} \mathrm{C}, 60^{\circ} \mathrm{C}, 65^{\circ} \mathrm{C}$ and $70^{\circ} \mathrm{C}$.

\section{Confirmation of the third disulfide bond formation}

Confirmation of the third disulfide bond formation was obtained from non reducing SDS-polyacrylamide gel electrophoresis and free $\mathrm{SH}$ residue measurement, ${ }^{12,13}$ in denaturing condition (7M guanidine $\mathrm{HCl}, 43 \mathrm{mM}$ Tris/ $\mathrm{HCl} \mathrm{pH} 8.0$ and $0.43 \mathrm{mg} / \mathrm{ml}$ EDTA), with L-Cysteine as standard

\section{RESULTS AND DISCUSSION}

Expression, refolding and purification of RNase T1S

Expression of RNase T1S, starting from 51 of culture broth, was performed in almost the same way as reported by Nishikawa et al, ${ }^{9,10}$ yielding subsequently $5.5 \mathrm{~g}$ of wet cells, and $247 \mathrm{mg}$ of protein mixture after DE 52 chromotography. After cyanogen bromide treatment, a considerable amount of precipitate appeared, indicating that a large portion of the enzyme was not in correct folding. It is clear that the additional disulfide bond in RNase T1S inhibited the establishment of the correct conformation after the urea was removed, perhaps due to random disulfide pairing. In RNaseT1, the conformation of the native protein molecule is the most stable, but under the influence of urea, random pairing of disulfide bonds will occur. ${ }^{14}$ RNase T1S has 6 cysteines compared to 4 in native RNase T1, so the possibility of incorrect pairing is much greater. Therefore, we used 2-mercaptoethanol to open the disulfide bonds and allowed the molecule to regain its correct conformation by hydrogen bonding, and then we used $100 \mathrm{mM} \mathrm{NaCl}$ in $50 \mathrm{mM}$ Tris/ $\mathrm{HCl} \mathrm{pH} 7.5$ to restore the disulfide bonds, as the reactivation of reduced RNase$\mathrm{T} 1$ is fast at neutral $\mathrm{pH}$ and in the presence of sodium chloride. ${ }^{14}$ After the refolding procedure, almost all of the precipitate dissapeared and yielded $177.5 \mathrm{mg}$ of protein mixture, which was subjected to $Q$ sepharose column chromatography and resulted in 2 major peaks. Both peaks $($ T1SI $=13.6 \mathrm{mg}$, TISII $=6.7 \mathrm{mg}$ ) were collected and subsequently purified by mono Q HPLC (yielding $9.5 \mathrm{mg}$ of T1SI and $5.9 \mathrm{mg}$ of T1SII) and sephadex G25 column (yielding $5.1 \mathrm{mg}$ of T1SI and $4.2 \mathrm{mg}$ of T1SII). Both were checked by sdspolyacrilamide gel electrophoresis and shown to have been purified to homogeneity (fig.3).

\section{Confirmation of the third disulfide bond formation}

Free $\mathrm{SH}$ residue measurement showed that both RNase T1SI and RNase T1SII had no free SH residue, suggesting that RNaseT1SI and RNaseT1SII are conformers, both containing 3 disulfide linkages.

Non reducing SDS-polyacrylamide gel electrophoresis (fig.3) showed that both RNase T1SI and RNase T1SII migrated faster than RNaseT1. This finding suggested that a third disulfide bond had been formed, as the disulfide linkage caused the protein to have a smaller radius of gyration and therefore migrated further down the gel ${ }^{3}$. The difference between RNaseT1SII is thought to be due to the difference in the SDS-denatured state of the two conformers.

Another evidence of the third disulfide bond formation came from peptide mapping experiments using $16 \mu \mathrm{g}$ of chymotrypsin in $100 \mu \mathrm{l}$ of $0.2 \mathrm{M} \mathrm{N}$-ethylmorpholine acetate buffer $\mathrm{pH} 8.0$ to digest $400 \mu \mathrm{g}$ heat denatured RNaseT1, RNaseT1SII (data not shown).

\section{Circular dichroism spectroscopy}

Circular dichroism measurements were performed at various temperatures. At $25^{\circ} \mathrm{C}$, in the $200-260 \mathrm{~nm}$ region, both RNase T1SI and RNase T1SII showed a more negative extrema at about $209 \mathrm{~nm}$ (fig.4). This fact is thought to be due to the change of tyrosine 24 residing in the middle of the $\alpha$ helix to cysteine 24 . This change would have stabilized the helix, as 


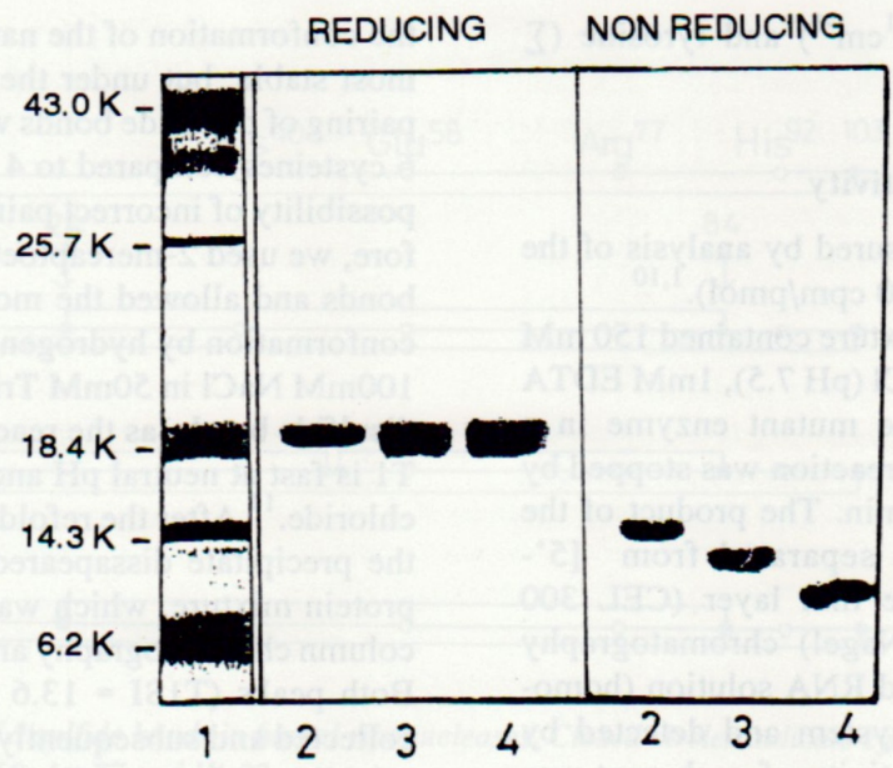

Figure 3. SDS-polyacrileamide gel electrophoresis (15\% SDS-PAGE) of purified $\boldsymbol{R}$ NaseT1. lane 1; molecular mass standard (values in KDa at side), lane 2; native $R$ NaseTI, lane 3; RNaseTISI, lane 4; RNaseTISII

a)

b)

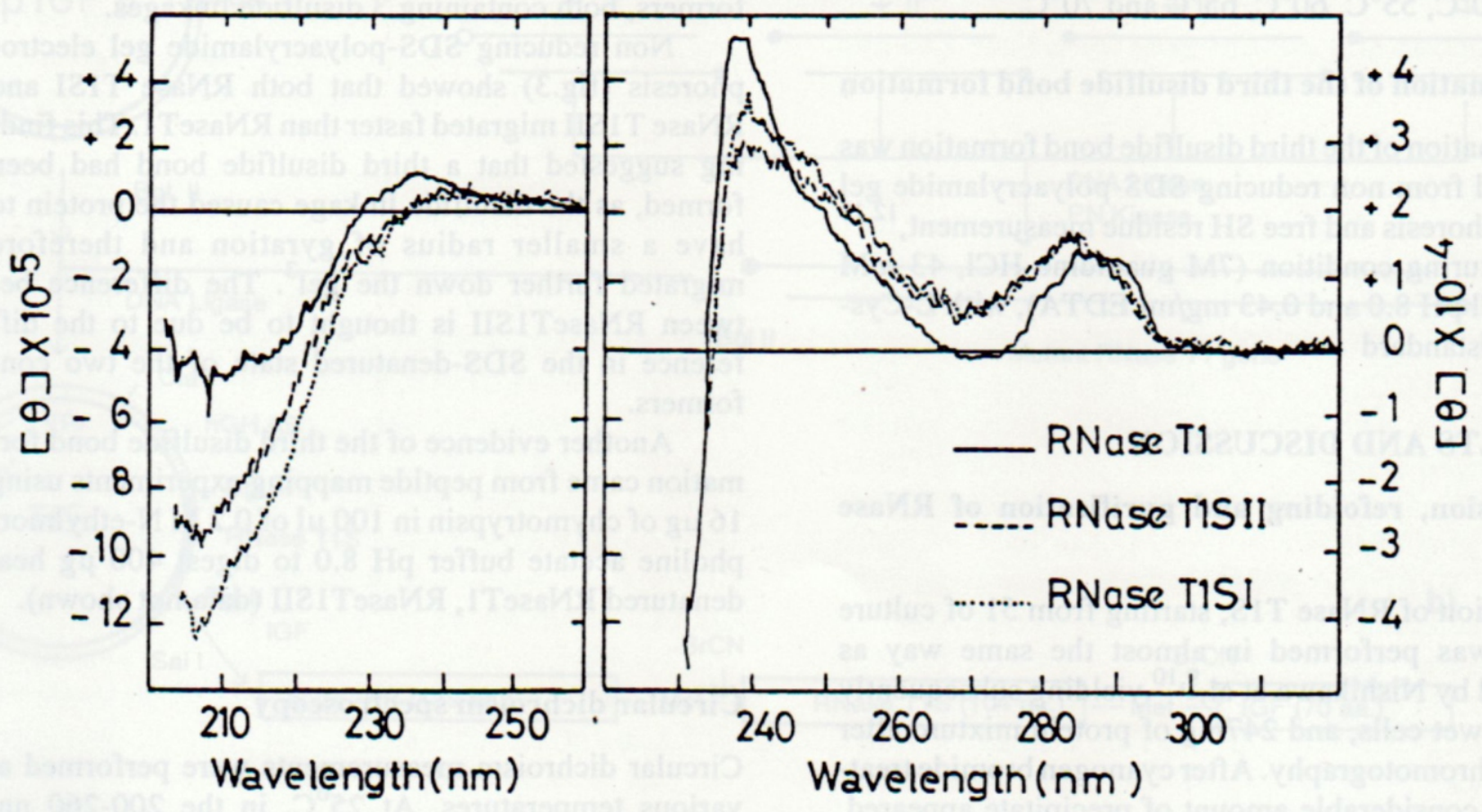

Figure 4. CD spectra of RNaseT1 and its mutants.

(a) CD spectra of wild type RNaseTI (-), RNaseTISI, (-..-) and RNaseTISII (-- at $0.05 \mu \mathrm{g}$ protein $/ \mu l$, in $\mathrm{H} 2 \mathrm{Q}$ at $25^{\circ} \mathrm{C}$.

(b) At $0.2 \mu$ g protein $/ \mu$ l, in $10 \mathrm{mM}$ potassium phosphate, pH 7.5 , at $25^{\circ} \mathrm{C}$. 


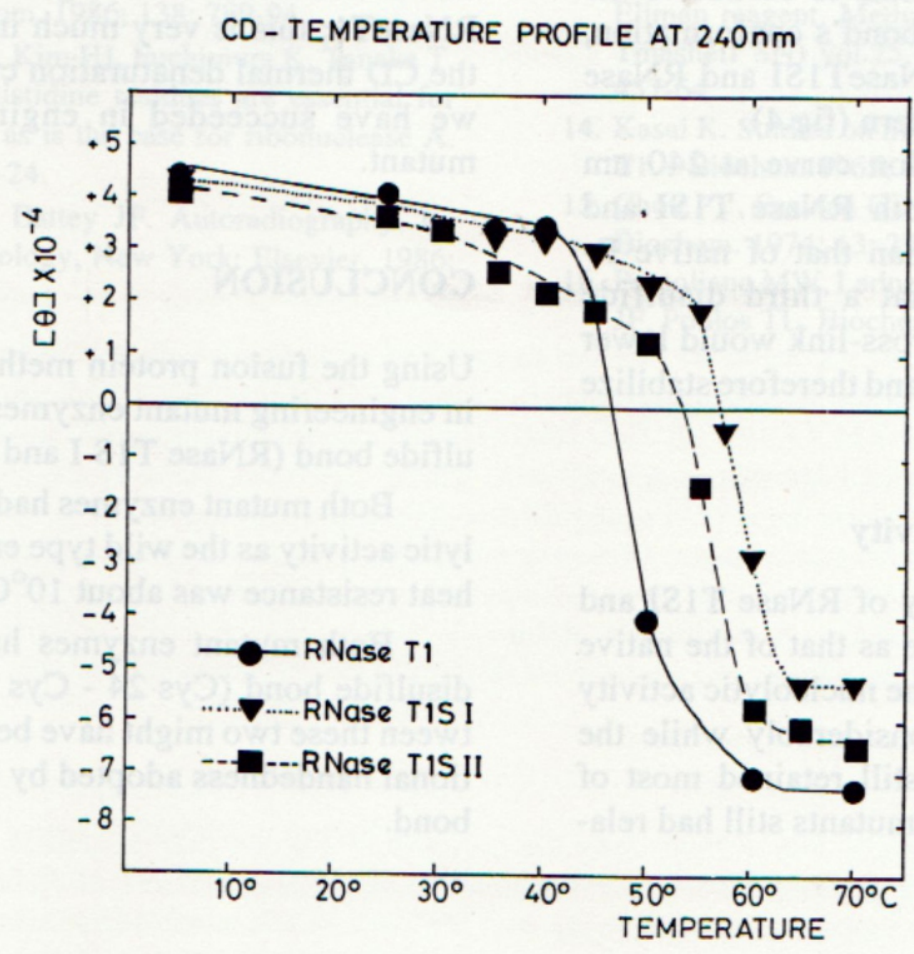

Figure 5. Thermal denaturation curves monitored by CD ellipticity at $240 \mathrm{~nm}$, for wild type RNaseT1, RNaseTISI and RNaseT1SII. The spectra was measured at $0.2 \mu \mathrm{g}$ protein/ $\mathrm{ml}$, in $10 \mathrm{mM}$ potassium phosphate, $\mathrm{pH} 7.5$, at $5^{\circ} \mathrm{C}, 25^{\circ} \mathrm{C}, 30^{\circ} \mathrm{C}, 35^{\circ} \mathrm{C}, 40^{\circ} \mathrm{C}, 45^{\circ} \mathrm{C}$, $50^{\circ} \mathrm{C}, 55^{\circ} \mathrm{C}, 60^{\circ} \mathrm{C}, 65^{\circ} \mathrm{C}$ and $70^{\circ} \mathrm{C}$, after a 15 min equilibration at each temperature.

\section{ACTIVITY-TEMPERATURE PROFILE}

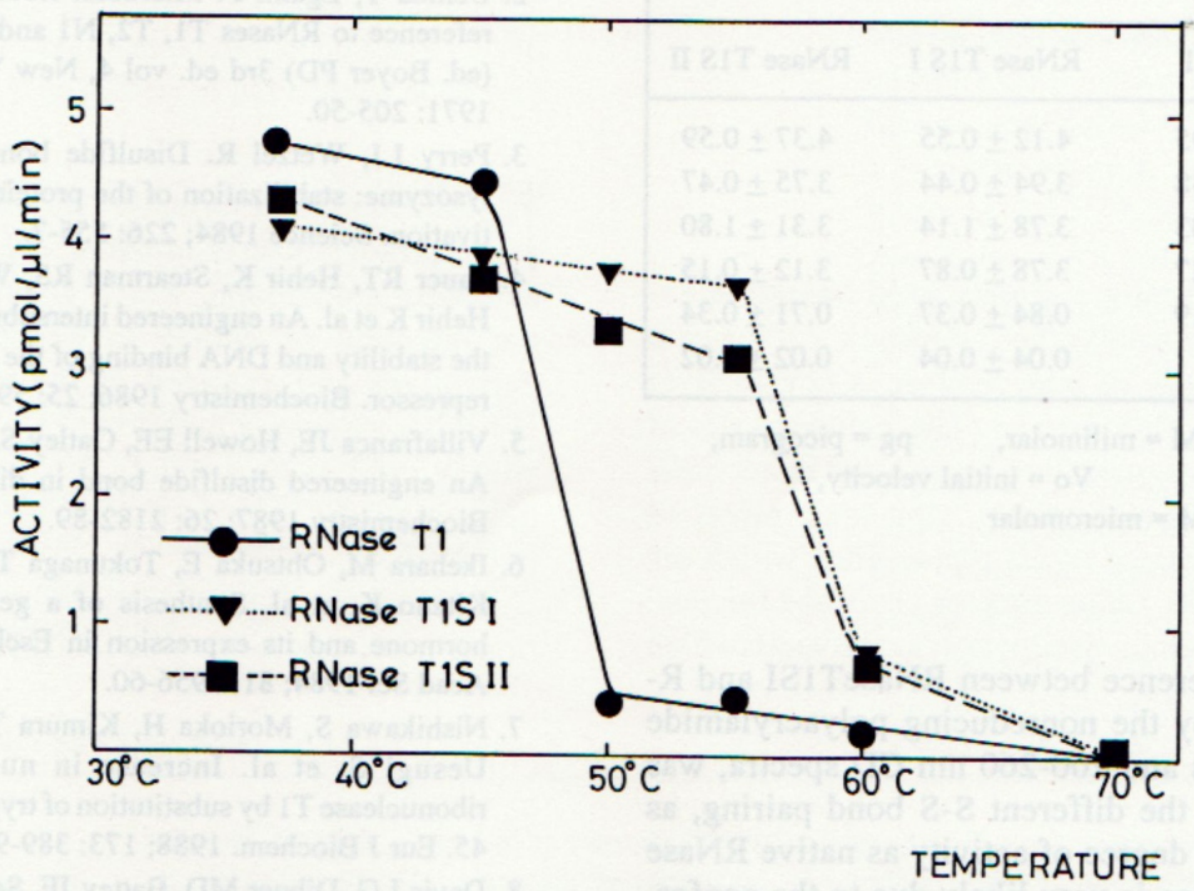

Figure 6. Thermal denaturation curves monitored by the initial velocity of pGpC cleavage by RNaseTI, RNaseT1SI and RNaseTISII. The initial velocities were measured at $37^{\circ} \mathrm{C}, 45^{\circ} \mathrm{C}, 50^{\circ} \mathrm{C}, 55^{\circ} \mathrm{C}, 60^{\circ} \mathrm{C}$, and $70^{\circ} \mathrm{C}$. 
tyrosine is an $\alpha$ helix breaker, while cystein is an $\alpha$ helix indifference residue. ${ }^{15}$ The difference between RNaseT1SI and RNaseT1SII seems to be due to the difference of the third disulfide bond's conformation, as in the $230-320 \mathrm{~nm}$ region RNaseT1SI and RNase T1SII showed a very similar pattern (fig.4).

The CD thermal denaturation curve at $240 \mathrm{~nm}$ showed that the structure of both RNase T1SI and RNaseT1SII was more stable than that of native RNaseT1 (fig.5), suggesting that a third disulfide linkage had been formed, as a cross-link would lower the entropy of the unfolded form and therefore stabilize the conformation. ${ }^{16}$

\section{Analysis of the nucleolytic activity}

At $37^{\circ} \mathrm{C}$, the nucleolytic activity of RNase T1SI and RNaseT1SII was about the same as that of the native RNaseT1 (table 1), but at $50^{\circ} \mathrm{C}$ the nucleolytic activity of native RNaseT1 dropped considerably while the RNase T1SI and RNaseT1SII still retained most of their activity. Even at $55^{\circ} \mathrm{C}$, the mutants still had relatively high activity (table 1 ).

Table 1. Initial velocity of $\mathrm{pGpC}$ cleavage by $\mathrm{RNase} \mathrm{T} 1$ and its mutants. Reaction mixture: substrate $150 \mathrm{mM}$, enzyme $5 \mathrm{pg} / \mu \mathrm{l}$, PH 7.5 Measured at $37^{\circ}, 45^{\circ} \mathrm{C}, 50^{\circ} \mathrm{C}, 55^{\circ} \mathrm{C}$, $60^{\circ} \mathrm{C}$ and $70^{\circ} \mathrm{C}$

\begin{tabular}{|cccc|}
\hline & \multicolumn{3}{c|}{ Vo $(\mu \mathrm{M} / \mathrm{min})$} \\
\cline { 2 - 4 } Temp & RNase T1 & RNase T1S I & RNase T1S II \\
\hline $37^{\circ} \mathrm{C}$ & $4.78 \pm 0.95$ & $4.12 \pm 0.55$ & $4.37 \pm 0.59$ \\
$45^{\circ} \mathrm{C}$ & $4.45 \pm 1.38$ & $3.94 \pm 0.44$ & $3.75 \pm 0.47$ \\
$50^{\circ} \mathrm{C}$ & $0.40 \pm 0.03$ & $3.78 \pm 1.14$ & $3.31 \pm 1.80$ \\
$55^{\circ} \mathrm{C}$ & $0.47 \pm 0.27$ & $3.78 \pm 0.87$ & $3.12 \pm 0.15$ \\
$60^{\circ} \mathrm{C}$ & $0.21 \pm 0.19$ & $0.84 \pm 0.37$ & $0.71 \pm 0.34$ \\
$70^{\circ} \mathrm{C}$ & 0 & $0.04 \pm 0.04$ & $0.02 \pm 0.02$ \\
\hline
\end{tabular}

$\min =$ minute,$\quad \mathrm{mM}=$ milimolar,$\quad \mathrm{pg}=$ picogram, RNase $=$ ribonuclease $\quad \mathrm{Vo}=$ initial velocity, $\mu \mathrm{l}=$ microliter,$\quad \mu \mathrm{M}=$ micromolar

Here the difference between RNaseTrSI and RNaseT1SII, seen by the nonreducing polyacrylamide gel electrophoresis and $200-260 \mathrm{~nm}$ CD spectra, was clearly not due to the different S-S bond pairing, as both had the same degree of activity as native RNase $\mathrm{T} 1$, so the difference is very likely due to the conformational handedness adopted by the third disulfide bond.
The activity-temperature profile (fig.6) showed that the heat resistance of both RNaseT1SI and RNaseT1SII was about $10^{\circ} \mathrm{C}$ higher than that of the native RNaseT1; this is very much in line with the result of the CD thermal denaturation curve and in this respect we have succeeded in engineering a more stable mutant.

\section{CONCLUSION}

Using the fusion protein method, we have succeeded in engineering mutant enzymes with an additional disulfide bond (RNase T1S I and RNase T1S II).

Both mutant enzymes had about the same nucleolytic activity as the wild type enzyme, but the mutant's heat resistance was about $10^{\circ} \mathrm{C}$ higher.

Both mutant enzymes had the same additional disulfide bond (Cys 24 - Cys 84). The difference between these two might have been due to the conformational handedness adopted by this additional disulfide bond.

\section{REFERENCES}

1. Ikehara M, Ohtsuka E, Tokunaga T, Nishikawa S, Uesugi S, Tanaka $\mathrm{T}$ et al. Inquiries into the structure-function relationship of ribonuclease $\mathrm{T} 1$ using chemically synthesized coding sequences. Proc Natl Acad Sci 1986; 83: 4695-9.

2. Uchida T, Egami F. Microbial ribonucleases with special reference to RNases T1, T2, N1 and U2. In: The enzymes (ed. Boyer PD) 3rd ed. vol 4, New York: Academic Press 1971: 205-50.

3. Perry LJ, Wetzel R. Disulfide bond engineered into T4 lysozyme: stabilization of the protein toward thermal inactivation. Science 1984; 226: 555-7.

4. Sauer RT, Hehir K, Stearman RS, Weiss MA, Jeitler NA, Hehir $\mathrm{K}$ et al. An engineered intersubunit disulfide enhances the stability and DNA binding of the $\mathrm{N}$ - terminal domain of repressor. Biochemistry 1986; 25: 5992-8.

5. Villafranca JE, Howell EE, Oatley SJ, Xuong NH, Kraut J. An engineered disulfide bond in dihydrofolate reductase. Biochemistry 1987; 26: 2182-89.

6. Ikehara M, Ohtsuka E, Tokunaga T, Taniyama I, Iwai S, Kitano K, et al. Synthesis of a gene for human growth hormone and its expression in Eschericia coli. Proc Natl Acad Sci 1984; 81: 5956-60.

7. Nishikawa S, Morioka H, Kimura T, Ueda Y, Tanaka T, Uesugi $S$, et al. Increase in nucleolytic activity of ribonuclease $\mathrm{T} 1$ by substitution of tryptophan $\mathbf{4 5}$ for tyrosine 45. Eur J Biochem. 1988; 173: 389-94.

8. Davis LG, Dibner MD, Battey JF. Sequencing M13 clones. In: Methods in molecular biology. New York : Elsevier, 1986: 268-73. 
9. Nishikawa S, Morioka H, Fuchimura K, Tanaka T, Uesugi S, Ohtsuka E, et al. Modification of Glu58, an amino acid of the active center of ribonuclease $\mathrm{T} 1$, to Gln and Asp. Biochem Biophys Res Com. 1986; 138: 789-94.

10. Nishikawa S, Morioka H, Kim HJ, Fuchimura K, Tanaka T, Uesugi $\mathrm{S}$, et al. Two histidine residues are essential for ribonuclease $\mathrm{T} 1$ activity as is the case for ribonuclease $\mathrm{A}$. Biochem 1987; 26: 8620-24.

11. Davis LG, Dibner MD, Battey JF. Autoradiography. In. Methods in molecular biology, New York: Elsevier, 1986: 331-2.
12. Ellman GL. Tissue sulfhydryl groups. Arch Biochem Biophys 1959; 82: 70-7.

13. Habeeb AFSA. Reaction of protein sufhydryl groups with Ellman reagent. Methods in Enzymology (ed. Hirs CHW, Tmasheff SN) vol.25, New York: Academic Press, 1972: 457-64.

14. Kasai K. Studies on the reoxidation of reduced ribonuclease T1. J Biochem 1965; 57: 372-9.

15. Chou PY, Fasman GD. Prediction of protein conformation. Biochem. 1974; 13: 222-43.

16. Pantoliano MW, Ladner RC, Bryan PN, Rollence ML, Wood JF, Poulos TL. Biochem. 1987; 26: 2077-82. 